This paper was retracted on June 15, 2006 (Org. Lett. 2006, 8, 2899).

\title{
Cobalt-catalyzed Arylation of Azole Heteroarenes via Direct C-H Bond Functionalization
}

\author{
Bengü Sezen and Dalibor Sames*
}

Department of Chemistry, Columbia University, 3000 Broadway, New York, NY 10027

\section{Supporting Information}

\section{Results for Cobalt and Palladium-catalyzed Arylation of Benzo-azoles}

Table 1. Cobalt-catalyzed arylation of benzothiazole. A comparison with palladiumbased methods

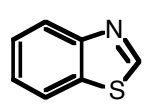

13

\begin{tabular}{|c|c|c|}
\hline entry & conditions & yield \\
\hline 1 & $\begin{array}{l}\mathrm{Co}(\mathrm{OAc})_{2} \text {, SALEN (10 mol\%), } \\
\text { dioxane, Cul (0.2 eq) }\end{array}$ & $87 \%$ \\
\hline 2 & $\begin{array}{l}\mathrm{Co}(\mathrm{OAc})_{2} \text {, IMes (10 mol\%), } \\
\text { dioxane, Cul (0.2 eq) }\end{array}$ & $90 \%$ \\
\hline 3 & $\begin{array}{l}\mathrm{Pd}(\mathrm{OAc})_{2}, \mathrm{Ph}_{3} \mathrm{P}(20 \mathrm{~mol} \%) \\
\mathrm{DMF}, \mathrm{Cul}(0.2 \mathrm{eq})\end{array}$ & $89 \%$ \\
\hline 4 & $\begin{array}{l}\text { control (no cat./ligand), } \\
\text { dioxane, Cul }(0.2 \mathrm{eq})\end{array}$ & traces \\
\hline
\end{tabular}

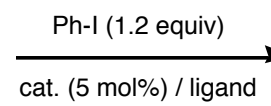

$\mathrm{Cs}_{2} \mathrm{CO}_{3}, 150 \mathrm{C}$

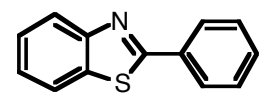

14

yield

Table 2. Cobalt-catalyzed arylation of benzoxazole. A comparison with palladiumbased methods

.


Table 3. Cobalt-catalyzed arylation of benzimidazole. A comparison with palladiumbased methods

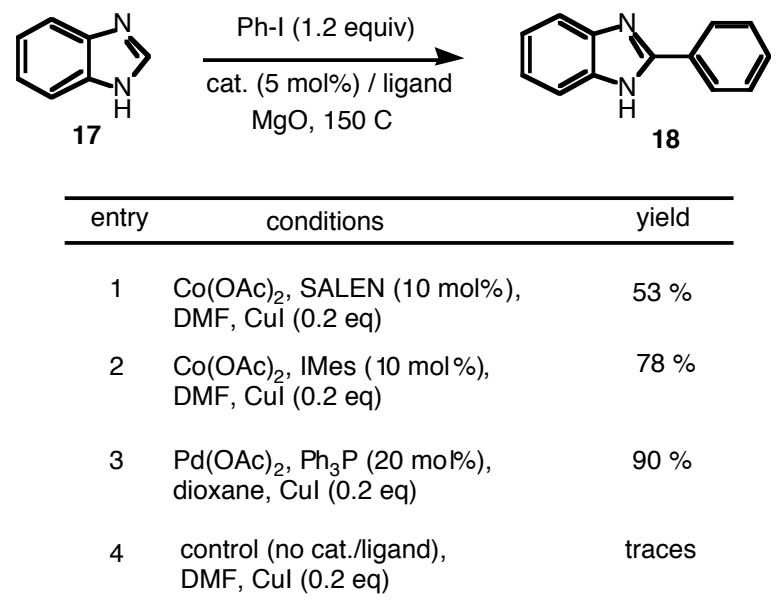

\section{Experimental Procedures and Characterization Data}

Anhydrous $\mathrm{Co}(\mathrm{OAc})_{2}$ was purchased from Aldrich and used without any further treatment. All starting heterocycles were purchased from Aldrich or Lancaster and used as received except for imidazole which was recrystallized from 1:2 mixture of dichloromethane and diethylether prior to use in arylation reactions. All aryl donors were purchased from Aldrich and used as received. Dioxane was dried over Na-benzophenone and DMF was dried by the alumina/copper catalyst solvent purification column.

$\mathrm{Co}(\mathrm{OAc})_{2}$ and $\mathrm{Cs}_{2} \mathrm{CO}_{3}$ are extremely hygroscopic and must be kept away from moisture. Anhydrous $\mathrm{Co}(\mathrm{OAc})_{2}$ was used throughout this study. Use of $\mathrm{Co}(\mathrm{OAc})_{2} \cdot \mathrm{xH}_{2} \mathrm{O}$ for the described methodology gives low to trace amount of yields. $\mathrm{Cs}_{2} \mathrm{CO}_{3}$ was dried at $150{ }^{\circ} \mathrm{C}$ under vacuo for 2 hours prior to each use.

Thiazole, oxazole and their mono-arylation products are volatile, care must be taken during the solvent evaporation step of arylation reactions of these compounds. The reactions were performed in closed systems (using pressure vessels having screw caps equipped with a resealable PTFE/silicone liner) due to the low boiling points of the starting materials an dioxane. 


\section{Procedure A: Catalytic arylation of thiazole at $\mathrm{C}-5$ with $\mathrm{Co}(\mathrm{OAc})_{2}$ / SALEN}

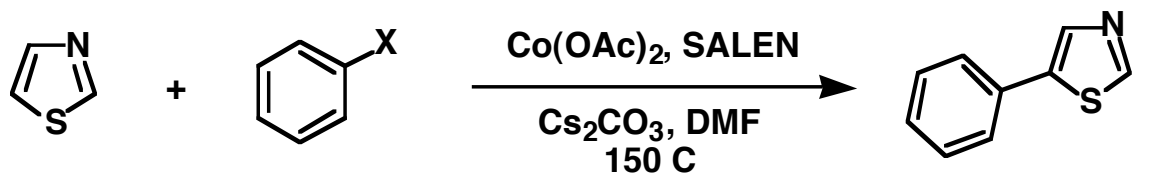

In a flame dried flask, anhydrous $\mathrm{Co}(\mathrm{OAc})_{2}(3.7 \mathrm{mg}, 0.021 \mathrm{mmol}, 5 \mathrm{~mol} \%)$ and SALEN [ethylenebis(salicylimine)] (11.0 mg, $0.041 \mathrm{mmol}, 0.1$ equiv) in $0.5 \mathrm{ml}$ dry DMF were stirred for $10 \mathrm{~min}$ at room temperature. Thiazole $(35 \mathrm{mg}, 0.411 \mathrm{mmol})$ in $1 \mathrm{ml}$ dry DMF and anhydrous $\mathrm{Cs}_{2} \mathrm{CO}_{3}$ (160.7 $\mathrm{mg}, 0.493 \mathrm{mmol}, 1.2$ equiv) were added consecutively to the above mixture under argon. Phenyl iodide ( $100.7 \mathrm{mg}, 0.493 \mathrm{mmol}, 1.2$ equiv), which was dissolved in $0.5 \mathrm{ml}$ dry DMF, was added dropwise next and the reaction mixture was heated to $150{ }^{\circ} \mathrm{C}$ under argon. The reaction propagation was monitored by TLC and upon completion (after about 12 hours, when the relative amount of desired product reached its maxiumum, longer reaction times may lead to further arylation of the product) of the reaction, the resulting reaction mixture was diluted with $\mathrm{CHCl}_{3}(20 \mathrm{ml})$ and filtered through a pad of celite. The solvents were evaporated and 5-phenylthiazole $2(27.2 \mathrm{mg}$, $41 \%$ ) was isolated by flash column chromatography (gradient elution hexanes $\square 10 \%$ ethyl acetate $/ 90 \%$ hexanes). The spectral data for this compound are in agreement with the literature values. ${ }^{1}$

\section{Procedure B: Catalytic arylation of thiazole at C-5 with $\mathrm{Co}(\mathrm{OAc})_{2}$ / IMes}

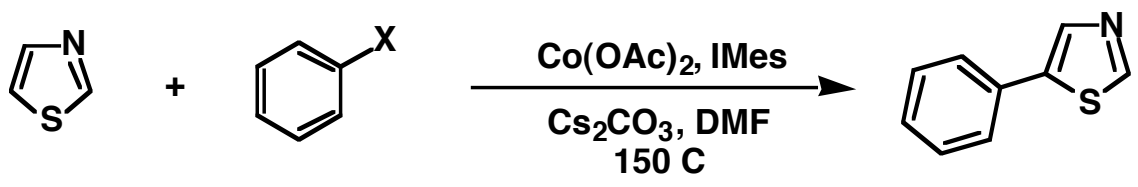

In a flame dried flask, anhydrous $\mathrm{Co}(\mathrm{OAc})_{2}(3.7 \mathrm{mg}, 0.021 \mathrm{mmol}, 5 \mathrm{~mol} \%), 1,3-$ bis(2,4,6-trimethylphenyl)imidazolium chloride (14.0 mg, $0.041 \mathrm{mmol}, 0.1$ equiv) and $\mathrm{K}_{3} \mathrm{PO}_{4}(8.8 \mathrm{mg}, 0.041 \mathrm{mmol}, 0.1$ equiv) in $0.5 \mathrm{ml}$ dry DMF were stirred for $10 \mathrm{~min}$ at room temperature. Thiazole $(35 \mathrm{mg}, 0.411 \mathrm{mmol})$ in $1 \mathrm{ml}$ dry DMF and anhydrous $\mathrm{Cs}_{2} \mathrm{CO}_{3}$ (160.7 mg, $0.493 \mathrm{mmol}, 1.2$ equiv) were added consecutively to the above mixture under argon. Phenyl iodide (100.7 mg, $0.493 \mathrm{mmol}, 1.2$ equiv), which was dissolved in $0.5 \mathrm{ml}$ dry DMF, was added dropwise next and the reaction mixture was heated to $150{ }^{\circ} \mathrm{C}$ under argon. The reaction propagation was monitored by TLC and upon completion (after about 12 hours, when the relative amount of desired product reached its maxiumum, longer reaction times may lead to further arylation of the product) of the reaction, the resulting reaction mixture was diluted with $\mathrm{CHCl}_{3}(20 \mathrm{ml})$ and filtered through a pad of celite. The solvents were evaporated and 5-phenylthiazole 2 (42.4 mg, $64 \%$ ) was isolated by flash column chromatography (gradient elution hexanes $\square 10 \%$ ethyl acetate / $90 \%$ hexanes). The spectral data for this compound are in agreement with the literature values. ${ }^{1}$ 


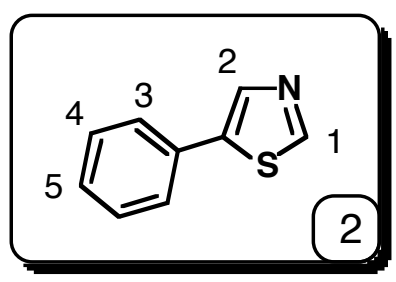

\begin{tabular}{ll}
${ }^{1} \mathrm{H}$ NMR data & $\left(400 \mathrm{MHz}, \mathrm{CDCl}_{3}\right)$ \\
\hline \hline $\mathrm{H}-1$ & $8.78,1 \mathrm{H}$, brs \\
$\mathrm{H}-2$ & $8.10,1 \mathrm{H}$, brs \\
$\mathrm{H}-3$ & $7.58-7.60,2 \mathrm{H}, \mathrm{m}$ \\
$\mathrm{H}-4, \mathrm{H}-5$ & $7.33-7.44,3 \mathrm{H}, \mathrm{m}$
\end{tabular}

${ }^{{ }^{13} \mathrm{C} \mathrm{NMR} \text { data }\left(100 \mathrm{MHz}, \mathrm{CDCl}_{3}\right)}$

126.6 (quat. C)

126.9 (2 C-H's)

$128.3(\mathrm{C}-\mathrm{H})$

128.9 (2 C-H's)

131.0 (quat. C)

$139.1(\mathrm{C}-\mathrm{H})$

$152.4(\mathrm{C}-\mathrm{H})$

IR (NaCl plate) $\square_{\max } 3061,2957,1653,1559,1540,1457,1379,1286 \mathrm{~cm}^{-1}$.

HRMS $\left(\mathrm{FAB}^{+}\right.$) calculated for $\mathrm{C}_{9} \mathrm{H}_{8} \mathrm{NS} \mathrm{m} / z, 162.0377$, observed $\mathrm{m} / \mathrm{z}, 162.0365$.

Procedure C: Catalytic arylation of thiazole at C-2 with $\mathrm{Co}(\mathrm{OAc})_{2}$ / SALEN / CuI<smiles>[X]c1ccccc1</smiles>

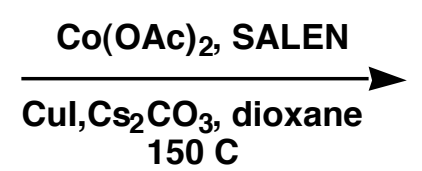<smiles>c1ccc(-c2nccs2)cc1</smiles>

In a flame dried flask, anhydrous $\mathrm{Co}(\mathrm{OAc})_{2}(3.7 \mathrm{mg}, 0.021 \mathrm{mmol}, 5 \mathrm{~mol} \%)$ and SALEN [ethylenebis(salicylimine)] (11.0 mg, $0.041 \mathrm{mmol}, 0.1$ equiv) in $0.5 \mathrm{ml}$ dry dioxane were stirred for $10 \mathrm{~min}$ at room temperature. Thiazole $(35 \mathrm{mg}, 0.411 \mathrm{mmol})$ in $1 \mathrm{ml}$ dry dioxane, anhydrous $\mathrm{Cs}_{2} \mathrm{CO}_{3}(160.7 \mathrm{mg}, 0.493 \mathrm{mmol}, 1.2$ equiv) and $\mathrm{CuI}(156.5 \mathrm{mg}, 0.822$ mmol, 2 equiv) were added consecutively to the above mixture under argon. Phenyl iodide (100.7 mg, $0.493 \mathrm{mmol}, 1.2$ equiv), which was dissolved in $0.5 \mathrm{ml}$ dry dioxane, was added dropwise next and the reaction mixture was heated to $150{ }^{\circ} \mathrm{C}$ under argon. The reaction propagation was monitored by TLC and upon completion (after about 10 hours, when the relative amount of desired product reached its maxiumum, longer reaction times may lead to further arylation of the product) of the reaction, the resulting reaction mixture was diluted with $\mathrm{CHCl}_{3}(20 \mathrm{ml})$ and filtered through a pad of celite. The solvents were evaporated and 2-phenylthiazole $3(57.7 \mathrm{mg}, 87 \%)$ was isolated by flash column chromatography (gradient elution hexanes $\square 10 \%$ ethyl acetate / $90 \%$ hexanes). The spectral data for this compound are in agreement with the literature values. ${ }^{2}$ 


\section{Procedure D: Catalytic arylation of thiazole at $\mathrm{C}-2$ with $\mathrm{Co}(\mathrm{OAc})_{2}$ / IMes / $\mathrm{CuI}$}

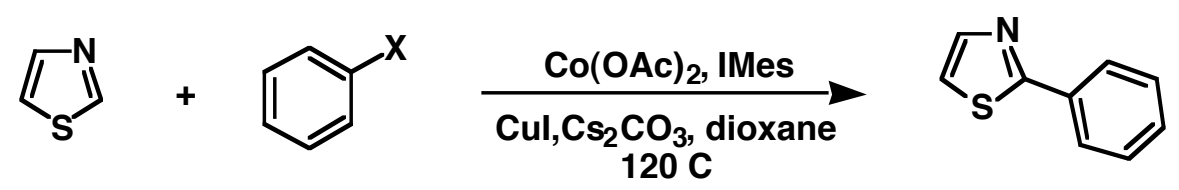

In a flame dried flask, anhydrous $\mathrm{Co}(\mathrm{OAc})_{2}(3.7 \mathrm{mg}, 0.021 \mathrm{mmol}, 5 \mathrm{~mol} \%), 1,3-$ bis(2,4,6-trimethylphenyl)imidazolium chloride (14.0 mg, $0.041 \mathrm{mmol}, 0.1$ equiv) and $\mathrm{K}_{3} \mathrm{PO}_{4}(8.8 \mathrm{mg}, 0.041 \mathrm{mmol}, 0.1$ equiv) in $0.5 \mathrm{ml}$ dry dioxane were stirred for $10 \mathrm{~min}$ at room temperature. Thiazole $(35 \mathrm{mg}, 0.411 \mathrm{mmol})$ in $1 \mathrm{ml}$ dry dioxane, anhydrous $\mathrm{Cs}_{2} \mathrm{CO}_{3}$ ( $160.7 \mathrm{mg}, 0.493 \mathrm{mmol}, 1.2$ equiv) and CuI (156.5 mg, $0.822 \mathrm{mmol}, 2$ equiv) were added consecutively to the above mixture under argon. Phenyl iodide (100.7 $\mathrm{mg}, 0.493 \mathrm{mmol}$, 1.2 equiv), which was dissolved in $0.5 \mathrm{ml}$ dry dioxane, was added dropwise next and the reaction mixture was heated to $120{ }^{\circ} \mathrm{C}$ under argon. The reaction propagation was monitored by TLC and upon completion (after about 10 hours, when the relative amount of desired product reached its maxiumum, longer reaction times may lead to further arylation of the product) of the reaction, the resulting reaction mixture was diluted with $\mathrm{CHCl}_{3}(20 \mathrm{ml})$ and filtered through a pad of celite. The solvents were evaporated and 2phenylthiazole $3(55.7 \mathrm{mg}, 84 \%)$ was isolated by flash column chromatography (gradient elution hexanes $\square 10 \%$ ethyl acetate / $90 \%$ hexanes). The spectral data for this compound are in agreement with the literature values. ${ }^{2}$

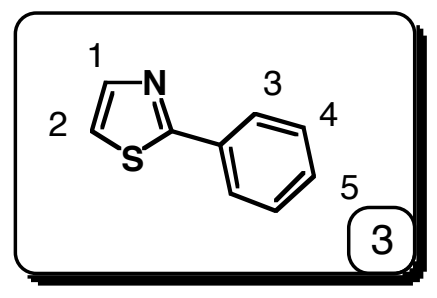

\begin{tabular}{ll}
${ }^{1} \mathrm{H}$ NMR data $\left(400 \mathrm{MHz}, \mathrm{CDCl}_{3}\right)$ \\
\hline \hline $\mathrm{H}-1$ & $7.87,1 \mathrm{H}, \mathrm{d}, \mathrm{J}=3.3 \mathrm{~Hz}$ \\
$\mathrm{H}-2$ & $7.33,1 \mathrm{H}, \mathrm{d}, \mathrm{J}=3.3 \mathrm{~Hz}$ \\
$\mathrm{H}-3$ & $7.95-7.98,2 \mathrm{H}, \mathrm{m}$ \\
$\mathrm{H}-4$ and $\mathrm{H}-5$ & $7.39-7.45,3 \mathrm{H}, \mathrm{m}$
\end{tabular}

\begin{tabular}{c}
${ }^{13} \mathrm{C}$ NMR data $\left(100 \mathrm{MHz}, \mathrm{CDCl}_{3}\right)$ \\
\hline \hline $118.9(\mathrm{C}-\mathrm{H})$ \\
$126.7(2 \mathrm{C}-\mathrm{H}$ 's $)$ \\
$129.1(2 \mathrm{C}-\mathrm{H}$ 's $)$ \\
$130.1(\mathrm{C}-\mathrm{H})$ \\
133.7 (quat. C) \\
143.8 (C-H) \\
168.4 (quat. C)
\end{tabular}

IR (NaCl plate) $\square_{\max } 3111,3081,1509,1479,1442,1411,1240 \mathrm{~cm}^{-1}$. HRMS (EI ${ }^{+}$) calculated for $\mathrm{C}_{9} \mathrm{H}_{7} \mathrm{SN} \mathrm{m} / z$ 161.0299, observed $\mathrm{m} / z, 161.0308$. 
2,5-Diphenylthiazole 4 was obtained as a side product of the $\mathrm{Pd}(\mathrm{OAc})_{2}$ catalyzed arylation reaction of thiazole. The spectral data for this compound are in agreement with the literature values. ${ }^{2}$

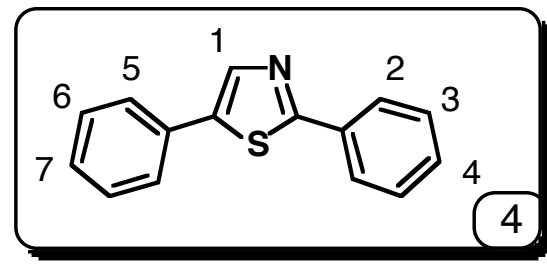

\begin{tabular}{ll}
\multicolumn{1}{l}{${ }^{1} \mathrm{H}$ NMR data } & $\left(400 \mathrm{MHz}, \mathrm{CDCl}_{3}\right)$ \\
\hline \hline $\mathrm{H}-1$ & $8.02,1 \mathrm{H}, \mathrm{s}$ \\
$\mathrm{H}-2$ & $7.97,2 \mathrm{H}, \mathrm{dd}, \mathrm{J}_{1}=1.6, \mathrm{~J}_{2}=7.7 \mathrm{~Hz}$ \\
$\mathrm{H}-3, \mathrm{H}-4, \mathrm{H}-6$ & $7.39-7.47,5 \mathrm{H}, \mathrm{m}$ \\
$\mathrm{H}-5$ & $7.61,2 \mathrm{H}, \mathrm{J}_{1}=1.4, \mathrm{~J}_{2}=7.3 \mathrm{~Hz}$ \\
$\mathrm{H}-7$ & $7.34,1 \mathrm{H}, \mathrm{tt}, \mathrm{J}_{1}=2.1, \mathrm{~J}_{2}=7.4 \mathrm{~Hz}$
\end{tabular}

\begin{tabular}{c}
${ }^{13} \mathrm{C}$ NMR data $\left(100 \mathrm{MHz}, \mathrm{CDCl}_{3}\right)$ \\
\hline \hline $126.2(2 \mathrm{C}-\mathrm{H}$ 's $)$ \\
126.4 (quat. C) \\
$126.5(2 \mathrm{C}-\mathrm{H}$ 's $)$ \\
$128.2(\mathrm{C}-\mathrm{H})$ \\
$128.8(2 \mathrm{C}-\mathrm{H}$ 's $)$ \\
$129.0(2 \mathrm{C}-\mathrm{H}$ 's $)$ \\
129.9 (C-H) \\
131.3 (quat.C) \\
133.6 (quat. C) \\
139.1 (C-H) \\
167.0 (quat. C)
\end{tabular}

IR (NaCl plate) $\square_{\max } 3056,2920,1521,1480,1446,1066 \mathrm{~cm}^{-1}$.

HRMS (EI ${ }^{+}$) calculated for $\mathrm{C}_{15} \mathrm{H}_{11} \mathrm{SN} \mathrm{m} / z$ 237.0612, observed $\mathrm{m} / z$ z 237.0602 .

5-Phenyloxazole 6 was obtained from oxazole in $18 \%$ yield by following procedure A and in $34 \%$ yield by following procedure B. The spectral data for this compound are in agreement with the literature values. ${ }^{3}$

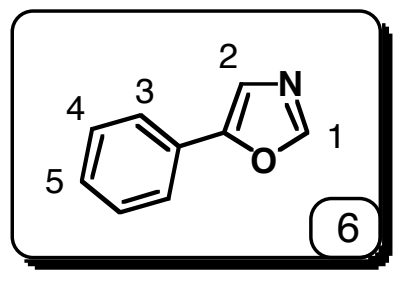

\begin{tabular}{lc}
\multicolumn{2}{c}{$\mathrm{H}$ NMR data $\left(400 \mathrm{MHz}, \mathrm{CDCl}_{3}\right)$} \\
\hline \hline $\mathrm{H}-1$ & $7.88,1 \mathrm{H}$, brs \\
$\mathrm{H}-2, \mathrm{H}-4, \mathrm{H}-5$ & $7.23-7.46,4 \mathrm{H}, \mathrm{m}$ \\
$\mathrm{H}-3$ & $7.60-7.63,2 \mathrm{H}, \mathrm{m}$
\end{tabular}

\begin{tabular}{c}
${ }^{13} \mathrm{C}$ NMR data $\left(100 \mathrm{MHz}, \mathrm{CDCl}_{3}\right)$ \\
\hline \hline $124.4(\mathrm{C}-\mathrm{H})$ \\
$127.8(2 \mathrm{C}-\mathrm{H} ' \mathrm{~s})$ \\
$128.7(\mathrm{C}-\mathrm{H})$ \\
$128.9(2 \mathrm{C}-\mathrm{H}$ 's $)$ \\
150.6 (quat. C) \\
$151.6(\mathrm{C}-\mathrm{H})$
\end{tabular}

IR (NaCl plate) $\square_{\max } 3068,1725,1669,1465,1373,1249 \mathrm{~cm}^{-1}$.

HRMS $\left(\mathrm{FAB}^{+}\right.$) calculated for $\mathrm{C}_{9} \mathrm{H}_{8} \mathrm{ON} \mathrm{m} / \mathrm{z}, 146.0606$, observed $\mathrm{m} / \mathrm{z} 146.0602$. 
2-Phenyloxazole 7 was obtained in $53 \%$ yield from oxazole by following procedure $\mathbf{C}$ and in $73 \%$ yield by following procedure $\mathbf{D}$. The spectral data for this compound are in agreement with the literature values. ${ }^{4}$

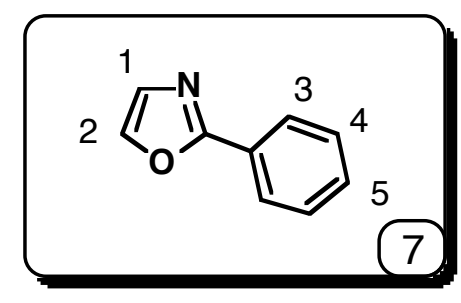

\begin{tabular}{ll}
${ }^{1} \mathrm{H}$ NMR data $\left(400 \mathrm{MHz}, \mathrm{CDCl}_{3}\right)$ \\
\hline \hline $\mathrm{H}-1$ & $7.22,1 \mathrm{H}, \mathrm{d}, \mathrm{J}=0.7 \mathrm{~Hz}$ \\
$\mathrm{H}-2$ & $7.68,1 \mathrm{H}, \mathrm{d}, \mathrm{J}=0.7 \mathrm{~Hz}$ \\
$\mathrm{H}-3$ & $8.03-8.06,2 \mathrm{H}, \mathrm{m}$ \\
$\mathrm{H}-4$ and $\mathrm{H}-5$ & $7.41-7.45,3 \mathrm{H}, \mathrm{m}$
\end{tabular}

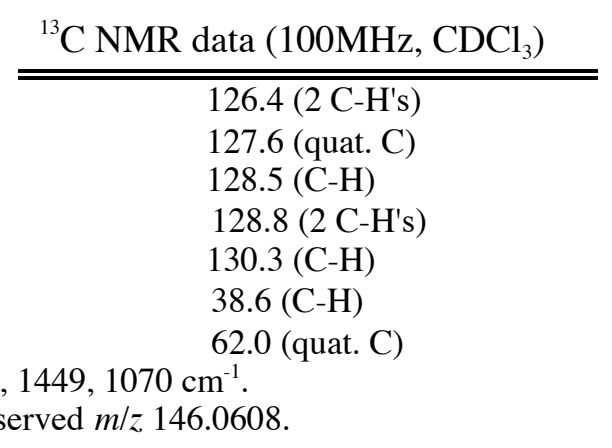

2,5-Diphenyloxazole 8 was obtained as a side product of the $\mathrm{Pd}(\mathrm{OAc})_{2}$ catalyzed arylation reaction of oxazole. The spectral data for this compound are in agreement with the literature values. ${ }^{2}$

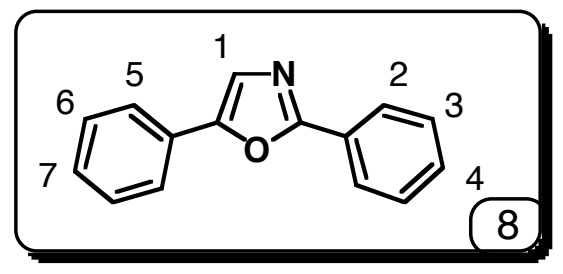

\begin{tabular}{ll}
\multicolumn{1}{l}{$\mathrm{H}_{\mathrm{NMR}}$ data $\left(400 \mathrm{MHz}, \mathrm{CDCl}_{3}\right)$} \\
\hline \hline $\mathrm{H}-1$ & $7.45,1 \mathrm{H}, \mathrm{s}$ \\
$\mathrm{H}-2$ & $8.10-8.13,2 \mathrm{H}, \mathrm{m}$ \\
$\mathrm{H}-3, \mathrm{H}-4, \mathrm{H}-6$ & $7.43-7.50,5 \mathrm{H}, \mathrm{m}$ \\
$\mathrm{H}-5$ & $7.71-7.74,2 \mathrm{H}, \mathrm{m}$ \\
$\mathrm{H}-7$ & $7.34,1 \mathrm{H}, \mathrm{tt}, \mathrm{J}_{1}=1.2, \mathrm{~J}_{2}=7.4 \mathrm{~Hz}$
\end{tabular}

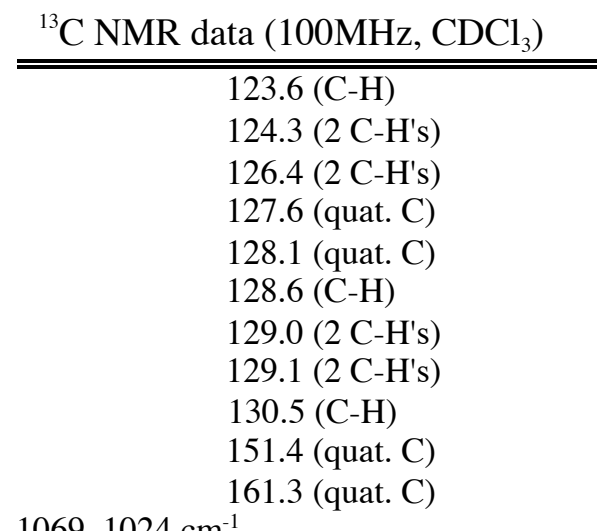

IR ( $\mathrm{NaCl}$ plate) $\square_{\max } 3118,3059,1587,1481,1445,1133,1069,1024 \mathrm{~cm}^{-1}$. HRMS (EI ${ }^{+}$) calculated for $\mathrm{C}_{15} \mathrm{H}_{11} \mathrm{ON} \mathrm{m} / z, 221.0841$, observed $\mathrm{m} / \mathrm{z} 221.0835$. 
2-Phenylbenzothiazole 14 was obtained in $87 \%$ yield from benzothiazole by following procedure $\mathbf{C}$ and in $90 \%$ yield by following procedure $\mathbf{D}$ (using 0.2 equiv of $\mathrm{CuI}$ instead of 2 equiv). The spectral data for this compound are in agreement with the literature values. $^{5}$

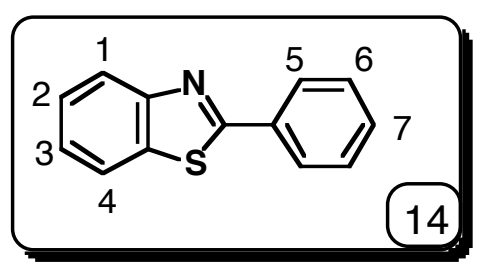

\begin{tabular}{ll}
${ }^{1} \mathrm{H}$ NMR data $\left(400 \mathrm{MHz}, \mathrm{CDCl}_{3}\right)$ \\
\hline \hline $\mathrm{H}-1$ & $7.86,1 \mathrm{H}, \mathrm{d}, \mathrm{J}=8.0 \mathrm{~Hz}$ \\
$\mathrm{H}-2-\mathrm{H}-4$ & $8.06-8.09,3 \mathrm{H}, \mathrm{m}$ \\
$\mathrm{H}-5-\mathrm{H}-7$ & $7.31-7.37,1 \mathrm{H}, \mathrm{m}$ \\
& $7.43-7.49,4 \mathrm{H}, \mathrm{m}$
\end{tabular}

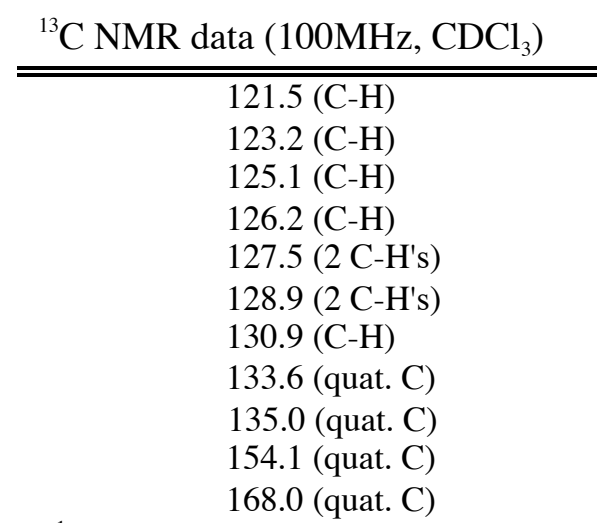

IR (NaCl plate) $\square_{\max } 3056,1623,1572,1441,1214,1053 \mathrm{~cm}^{-1}$.

2-Phenylbenzoxazole 16 was obtained in $91 \%$ yield from benzoxazole by following procedure $\mathbf{C}$ and in $92 \%$ yield by following procedure $\mathbf{D}$ (using 0.2 equiv of $\mathrm{CuI}$ instead of 2 equiv). The spectral data for this compound are in agreement with the literature values. ${ }^{6}$

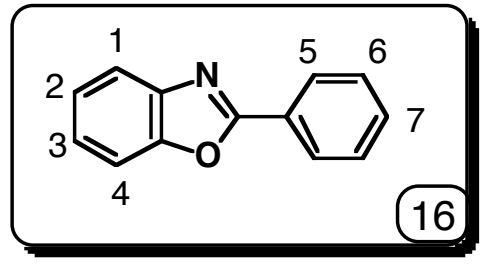

\begin{tabular}{cc}
${ }^{1} \mathrm{H}$ NMR data $\left(400 \mathrm{MHz}, \mathrm{CDCl}_{3}\right)$ \\
\hline \hline $\mathrm{H}-1-\mathrm{H}-4$ & $7.55-7.57,1 \mathrm{H}, \mathrm{m}$ \\
& $7.76-7.78,1 \mathrm{H}, \mathrm{m}$ \\
$\mathrm{H}-5-\mathrm{H}-7$ & $8.23-8.26,2 \mathrm{H}, \mathrm{m}$ \\
& $7.32-7.35,2 \mathrm{H}, \mathrm{m}$ \\
& $7.49-7.52,3 \mathrm{H}, \mathrm{m}$
\end{tabular}

IR (NaCl plate) $\square_{\max } 3052,1632,1544,1452,1427 \mathrm{~cm}^{-1}$.

\begin{tabular}{c}
${ }^{13} \mathrm{C}$ NMR data $\left(100 \mathrm{MHz}, \mathrm{CDCl}_{3}\right)$ \\
\hline \hline $110.5(\mathrm{C}-\mathrm{H})$ \\
$120.0(\mathrm{C}-\mathrm{H})$ \\
$124.5(\mathrm{C}-\mathrm{H})$ \\
$125.0(\mathrm{C}-\mathrm{H})$ \\
127.1 (quat. C) \\
$127.6(2 \mathrm{C}-\mathrm{H}$ 's) \\
$128.8(2 \mathrm{C}-\mathrm{H}$ 's) \\
$131.4(\mathrm{C}-\mathrm{H})$ \\
142.1 (quat. C) \\
150.7 (quat. C) \\
163.0 (quat. C)
\end{tabular}




\section{Procedure E: Catalytic arylation of imidazole at $\mathrm{C}-5$ with $\mathrm{Co}(\mathrm{OAc})_{2}$ / SALEN}

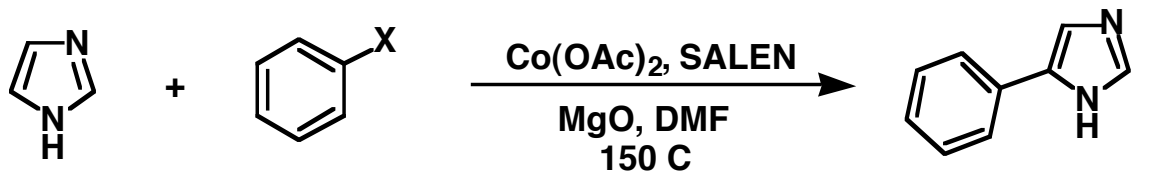

In a flame dried flask, anhydrous $\mathrm{Co}(\mathrm{OAc})_{2}(3.9 \mathrm{mg}, 0.022 \mathrm{mmol}, 5 \mathrm{~mol} \%)$ and SALEN [ethylenebis(salicylimine)] (11.8 $\mathrm{mg}, 0.044 \mathrm{mmol}, 0.1$ equiv) in $0.5 \mathrm{ml}$ dry DMF were stirred for $10 \mathrm{~min}$ at room temperature. Imidazole $(30 \mathrm{mg}, 0.441 \mathrm{mmol})$ in $1 \mathrm{ml}$ dry DMF and $\mathrm{MgO}$ (21.3 mg, $0.529 \mathrm{mmol}, 1.2$ equiv) were added consecutively to the above mixture under argon and the resultant mixture was stirred vigorously for an additional 10 min. (A homogeneous suspension must be obtained at this point, without any purple undissolved $\mathrm{Co}(\mathrm{OAc})_{2}$ or big particles of $\mathrm{MgO}$ at the bottom of the flask). Phenyl iodide (107.9 mg, $0.529 \mathrm{mmol}, 1.2$ equiv), which was dissolved in $0.5 \mathrm{ml}$ dry DMF, was added dropwise next and the reaction mixture was heated to $150{ }^{\circ} \mathrm{C}$ under argon. The reaction propagation was monitored by TLC and upon completion (after about 12 hours, when the relative amount of desired product reached its maximum, longer reaction times may lead to further arylation of the product) of the reaction, the resulting reaction mixture was diluted with $\mathrm{CHCl}_{3}(20 \mathrm{ml})$ and filtered through a pad of celite. The solvents were evaporated and 4(5)-phenylimidazole $10(17.2 \mathrm{mg}, 27 \%)$ was isolated by flash column chromatography (gradient elution hexanes $\square 20 \%$ ethyl acetate / $80 \%$ hexanes). The spectral data for this compound are in agreement with the literature values. ${ }^{7}$

\section{Procedure F: Catalytic arylation of imidazole at $\mathrm{C}-5$ with $\mathrm{Co}(\mathrm{OAc})_{2}$ / IMes}

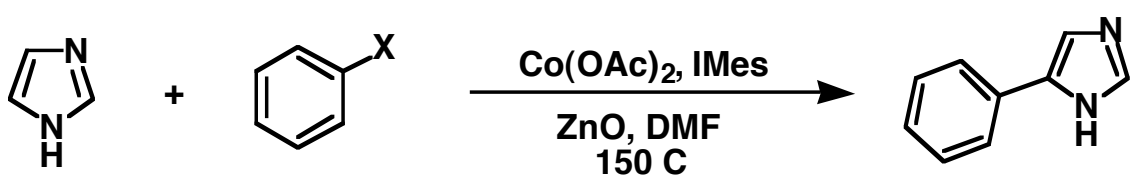

In a flame dried flask, anhydrous $\mathrm{Co}(\mathrm{OAc})_{2}(3.9 \mathrm{mg}, 0.022 \mathrm{mmol}, 5 \mathrm{~mol} \%), 1,3-$ bis(2,4,6-trimethylphenyl)imidazolium chloride $(15.0 \mathrm{mg}, 0.044 \mathrm{mmol}, 0.1$ equiv) and $\mathrm{K}_{3} \mathrm{PO}_{4}$ (9.4 mg, $0.044 \mathrm{mmol}, 0.1$ equiv) in $0.5 \mathrm{ml}$ dry DMF were stirred for $10 \mathrm{~min}$ at room temperature. Imidazole (30 mg, $0.441 \mathrm{mmol}$ ) in $1 \mathrm{ml}$ dry DMF and $\mathrm{ZnO}(43.0 \mathrm{mg}$, 0.529 mmol, 1.2 equiv) were added consecutively to the above mixture under argon and the resultant mixture was stirred vigorously for an additional $10 \mathrm{~min}$. (A homogeneous suspension must be obtained at this point, without any purple undissolved $\mathrm{Co}(\mathrm{OAc})_{2}$ or big particles of $\mathrm{ZnO}$ at the bottom of the flask). Phenyl iodide $(107.9 \mathrm{mg}, 0.529 \mathrm{mmol}$, 1.2 equiv), which was dissolved in $0.5 \mathrm{ml}$ dry DMF, was added dropwise next and the reaction mixture was heated to $150{ }^{\circ} \mathrm{C}$ under argon. The reaction propagation was monitored by TLC and upon completion (after about 12 hours, when the relative amount of desired product reached its maximum, longer reaction times may lead to further arylation of the product) of the reaction, the resulting reaction mixture was diluted with $\mathrm{CHCl}_{3}(20 \mathrm{ml})$ and filtered through a pad of celite. The solvents were evaporated and 4(5)-phenylimidazole $10(26.0 \mathrm{mg}, 41 \%)$ was isolated by flash column chromatography (gradient elution hexanes $020 \%$ ethyl acetate / $80 \%$ hexanes). The spectral data for this compound are in agreement with the literature values. ${ }^{7}$ 


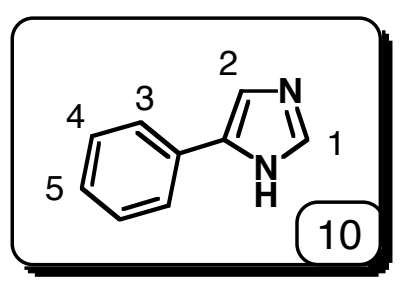

\begin{tabular}{lcc}
${ }^{1} \mathrm{H}$ NMR data $\left(400 \mathrm{MHz}, \mathrm{d}_{6}-\mathrm{DMSO}\right)$ & ${ }^{13} \mathrm{C}$ NMR data $\left(100 \mathrm{MHz}, \mathrm{d}_{6}-\mathrm{DMSO}\right)$ \\
\hline \hline $\mathrm{H}-1$ & $7.75,1 \mathrm{H}, \mathrm{s}$ & $114.7(\mathrm{C}-\mathrm{H})$ \\
$\mathrm{H}-2$ & $7.60,1 \mathrm{H}, \mathrm{s}$ & $124.1(2 \mathrm{C}-\mathrm{H} ' \mathrm{~s})$ \\
$\mathrm{H}-3$ & $7.78,2 \mathrm{H}, \mathrm{d}, \mathrm{J}=7.8 \mathrm{~Hz}$ & $126.0(\mathrm{C}-\mathrm{H})$ \\
$\mathrm{H}-4$ & $7.36,2 \mathrm{H}, \mathrm{t}, \mathrm{J}=7.7 \mathrm{~Hz}$ & $128.4(2 \mathrm{C}-\mathrm{H} ' \mathrm{~s})$ \\
$\mathrm{H}-5$ & $7.19,1 \mathrm{H}, \mathrm{t}, \mathrm{J}=7.4 \mathrm{~Hz}$ & 133.9 (quat. C) \\
$\mathrm{N}-\mathrm{H}$ & $12.33,1 \mathrm{H}, \mathrm{brs}$ & 135.9 (C-H) \\
\multicolumn{2}{l}{$\mathrm{IR}\left(\mathrm{NaCl}\right.$ plate) $\square_{\max } 3091,3060,1605,1462,1312,1118,1068 \mathrm{~cm}^{-1}}$. &
\end{tabular}

\section{Procedure G: Catalytic arylation of imidazole at C-2 with $\mathrm{Co}(\mathrm{OAc})_{2}$ / SALEN / CuI}

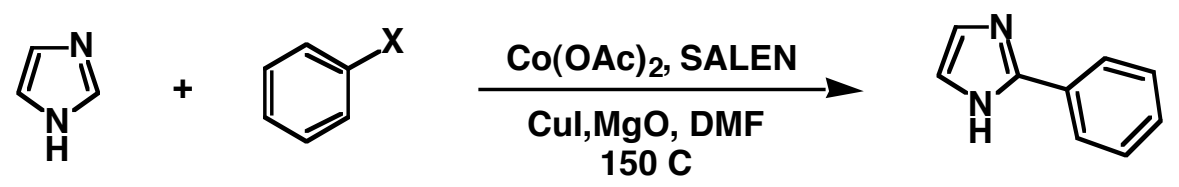

In a flame dried flask, anhydrous $\mathrm{Co}(\mathrm{OAc})_{2}(3.9 \mathrm{mg}, 0.022 \mathrm{mmol}, 5 \mathrm{~mol} \%)$ and SALEN [ethylenebis(salicylimine)] (11.8 $\mathrm{mg}, 0.044 \mathrm{mmol}, 0.1$ equiv) in $0.5 \mathrm{ml}$ dry DMF were stirred for $10 \mathrm{~min}$ at room temperature. Imidazole $(30 \mathrm{mg}, 0.441 \mathrm{mmol})$ in $1 \mathrm{ml}$ dry DMF and $\mathrm{MgO}$ (21.3 mg, $0.529 \mathrm{mmol}, 1.2$ equiv) were added consecutively to the above mixture under argon and the resultant mixture was stirred vigorously for an additional 10 min. (A homogeneous suspension must be obtained at this point, without any purple undissolved $\mathrm{Co}(\mathrm{OAc})_{2}$ or big particles of $\mathrm{MgO}$ at the bottom of the flask). $\mathrm{CuI}$ (167.8 $\mathrm{mg}$, $0.881 \mathrm{mmol}, 2$ equiv) and followed by phenyl iodide (107.9 $\mathrm{mg}, 0.529 \mathrm{mmol}, 1.2$ equiv), which was dissolved in $0.5 \mathrm{ml}$ dry DMF, were added next and the reaction mixture was heated to $150{ }^{\circ} \mathrm{C}$ under argon. The reaction propagation was monitored by TLC and upon completion (after about 12 hours, when the relative amount of desired product reached its maximum, longer reaction times may lead to further arylation of the product) of the reaction, the resulting reaction mixture was diluted with $\mathrm{CHCl}_{3}(20 \mathrm{ml})$ and filtered through a pad of celite. The solvents were evaporated and 2-phenylimidazole 11 (34.3 $\mathrm{mg}, 54 \%$ ) was isolated by flash column chromatography (gradient elution hexanes $\square 20$ $\%$ ethyl acetate / $80 \%$ hexanes). The spectral data for this compound are in agreement with the literature values. ${ }^{8}$ 


\section{Procedure H: Catalytic arylation of imidazole at $\mathrm{C}-2$ with $\mathrm{Co}(\mathrm{OAc})_{2} / \mathrm{IMes} / \mathrm{CuI}$}

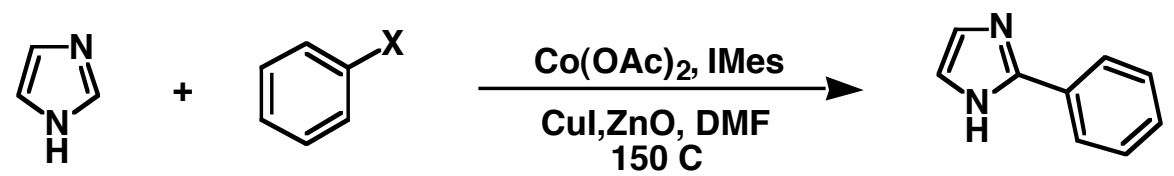

In a flame dried flask, anhydrous $\mathrm{Co}(\mathrm{OAc})_{2}(3.9 \mathrm{mg}, 0.022 \mathrm{mmol}, 5 \mathrm{~mol} \%), 1,3-$ bis(2,4,6-trimethylphenyl)imidazolium chloride $\mathrm{Cl}(15.0 \mathrm{mg}, 0.044 \mathrm{mmol}, 0.1$ equiv) and $\mathrm{K}_{3} \mathrm{PO}_{4}$ (9.4 mg, $0.044 \mathrm{mmol}, 0.1$ equiv) in $0.5 \mathrm{ml}$ dry DMF were stirred for $10 \mathrm{~min}$ at room temperature. Imidazole (30 mg, $0.441 \mathrm{mmol}$ ) in $1 \mathrm{ml}$ dry DMF and $\mathrm{ZnO}(43.0 \mathrm{mg}$, 0.529 mmol, 1.2 equiv) were added consecutively to the above mixture under argon and the resultant mixture was stirred vigorously for an additional $10 \mathrm{~min}$. (A homogeneous suspension must be obtained at this point, without any purple undissolved $\mathrm{Co}(\mathrm{OAc})_{2}$ or big particles of $\mathrm{ZnO}$ at the bottom of the flask). $\mathrm{CuI}(167.8 \mathrm{mg}, 0.881 \mathrm{mmol}, 2$ equiv) and followed by phenyl iodide ( $107.9 \mathrm{mg}, 0.529 \mathrm{mmol}, 1.2$ equiv), which was dissolved in $0.5 \mathrm{ml}$ dry DMF, were added next and the reaction mixture was heated to $150{ }^{\circ} \mathrm{C}$ under argon. The reaction propagation was monitored by TLC and upon completion (after about 12 hours, when the relative amount of desired product reached its maximum, longer reaction times may lead to further arylation of the product) of the reaction, the resulting reaction mixture was diluted with $\mathrm{CHCl}_{3}(20 \mathrm{ml})$ and filtered through a pad of celite. The solvents were evaporated and 2-phenylimidazole $11(49.6 \mathrm{mg}, 78 \%)$ was isolated by flash column chromatography (gradient elution hexanes $\square 20 \%$ ethyl acetate / $80 \%$ hexanes). The spectral data for this compound are in agreement with the literature values. $^{8}$

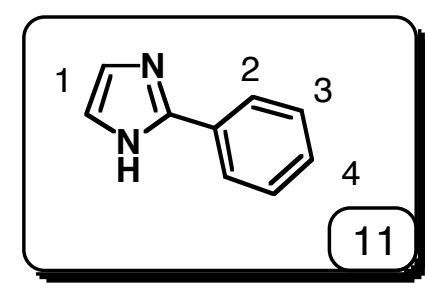

\begin{tabular}{llc}
${ }^{1} \mathrm{H} \mathrm{NMR}$ data $\left(400 \mathrm{MHz}, \mathrm{CDCl}_{3}\right)$ & ${ }^{13} \mathrm{C} \mathrm{NMR}$ data $\left(100 \mathrm{MHz}, \mathrm{CDCl}_{3}\right)$ \\
\hline \hline $\mathrm{H}-1$ & $7.13,2 \mathrm{H}, \mathrm{s}$ & $123.2(2 \mathrm{C}-\mathrm{H}$ 's $)$ \\
$\mathrm{H}-2$ & $7.86-7.90,2 \mathrm{H}, \mathrm{m}$ & $125.5(2 \mathrm{C}-\mathrm{H}$ 's $)$ \\
$\mathrm{H}-3, \mathrm{H}-4$ & $7.28-7.35,3 \mathrm{H}, \mathrm{m}$ & $128.5(\mathrm{C}-\mathrm{H})$ \\
$\mathrm{N}-\mathrm{H}$ & $11.23,1 \mathrm{H}$, brs & $128.8(2 \mathrm{C}-\mathrm{H}$ 's $)$ \\
& & 130.3 (quat. C) \\
& & $147.2($ quat. C)
\end{tabular}


2-Phenylbenzimidazole 18 was obtained in $53 \%$ yield from benzimidazole by following procedure $\mathbf{G}$, and in $78 \%$ yield by following procedure $\mathbf{H}$ (using 0.2 equiv of $\mathrm{CuI}$ instead of 2 equiv) and the spectral data for this compound are in agreement with the literature values. ${ }^{9}$

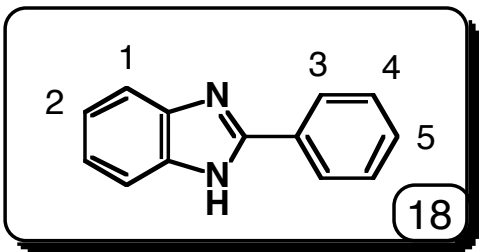

\begin{tabular}{lcc}
\multicolumn{2}{c}{$\mathrm{H}$ NMR data $\left(400 \mathrm{MHz}, \mathrm{d}_{6}-\mathrm{DMSO}\right)$} & ${ }^{13} \mathrm{C}$ NMR data $\left(100 \mathrm{MHz}, \mathrm{d}_{6}-\mathrm{DMSO}\right)$ \\
\hline \hline $\mathrm{H}-1$ & $8.22,2 \mathrm{H}, \mathrm{d}, \mathrm{J}=7.6 \mathrm{~Hz}$ & $115.3(2 \mathrm{C}-\mathrm{H}$ 's $)$ \\
$\mathrm{H}-2-\mathrm{H}-5$ & $7.20-7.23,2 \mathrm{H}, \mathrm{m}$ & $122.0(2 \mathrm{C}-\mathrm{H}$ 's $)$ \\
& $7.47-7.66,5 \mathrm{H}, \mathrm{m}$ & $126.3(2 \mathrm{C}-\mathrm{H}$ 's $)$ \\
$\mathrm{N}-\mathrm{H}$ & $12.98,1 \mathrm{H}, \mathrm{brs}$ & $128.8(2 \mathrm{C}-\mathrm{H}$ 's $)$ \\
& & 129.7 (C-H) \\
& & 130.1 (quat. C) \\
& & 134.9 (quat. C) \\
& & 143.7 (quat. C) \\
& 151.2 (quat. C)
\end{tabular}

IR (NaCl plate) $\square_{\max } 3166,3056,1661,1443,1050,1037 \mathrm{~cm}^{-1}$.

\section{References}

1. Pavlik, J. W.; Tongcharoensirikul, P.; Bird, N. P.; Day, A. C.; Barltrop, J. A. J. Am. Chem. Soc. 1994, 116, 2292.

2. Pivsa-Art, S.; Satoh, T.; Kawamura, Y.; Miura, M. Nomura, M. Bull. Chem. Soc. Jpn. 1998, 71, 467.

3. Kulkarni, B. A.; Ganesan, A. Tet. Lett. 1999, 40, 5633.

4. Prager, R. H.; Smith, J. A.; Weber, B.; Williams, C. M. J. Chem. Soc. Perkin Trans. 1 1997, 17, 2665.

5. The Aldrich Library of ${ }^{13} \mathrm{C}$ and ${ }^{1} \mathrm{H}$ FT NMR Spectra Ed.1, Pouchert, C. J.; Behnke, J. 1993, 3, 202-C.

6. The Aldrich Library of ${ }^{13} \mathrm{C}$ and ${ }^{1} \mathrm{H}$ FT NMR Spectra Ed.1, Pouchert, C. J.; Behnke, J. 1993, 3, 198-B.

7. The Aldrich Library of ${ }^{13} \mathrm{C}$ and ${ }^{1} \mathrm{H}$ FT NMR Spectra Ed.1, Pouchert, C. J.; Behnke, J. 1993, 3, 82A.

8. Foces, C.; Llamas-Saiz, A. L.; Claramunt, R. M.; Cabildo, P.; Elguero, J. J. Mol. Str. 1998, 440, 193.

9. The Aldrich Library of ${ }^{13} \mathrm{C}$ and ${ }^{1} \mathrm{H}$ FT NMR Spectra Ed.1, Pouchert, C. J.; Behnke, J. 1993, 3,180 A. 


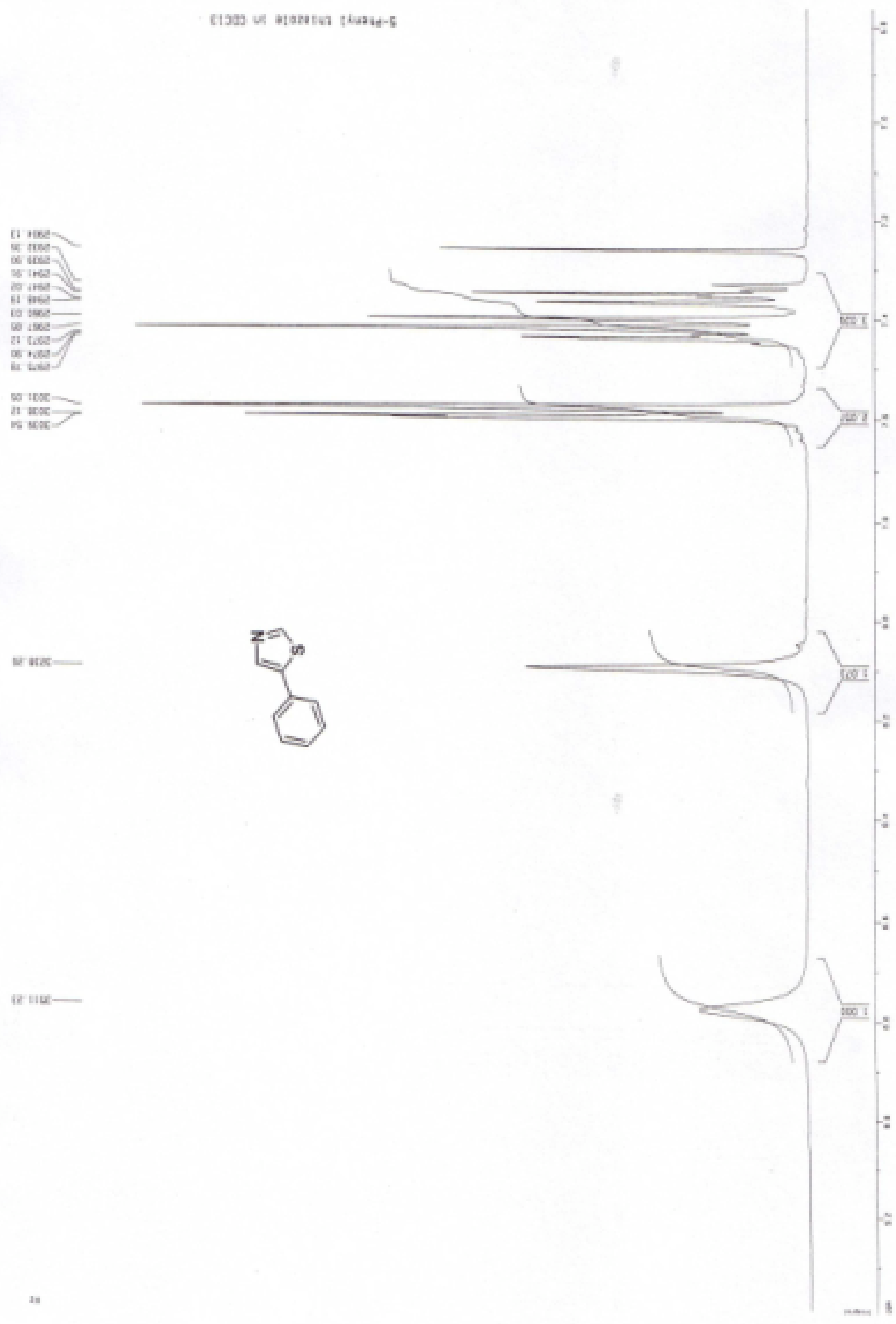




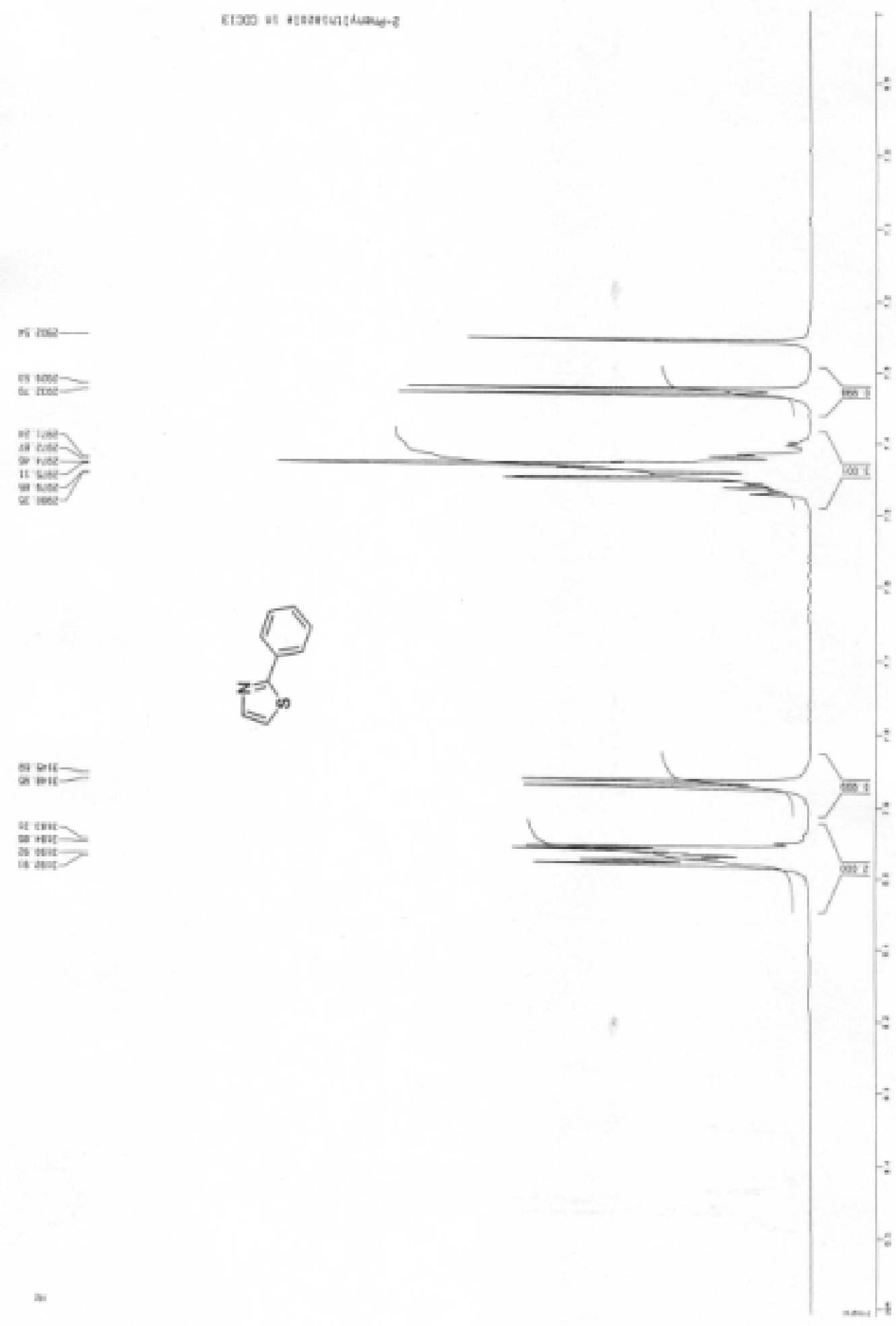


81ว3 of aedeiva thatatos?
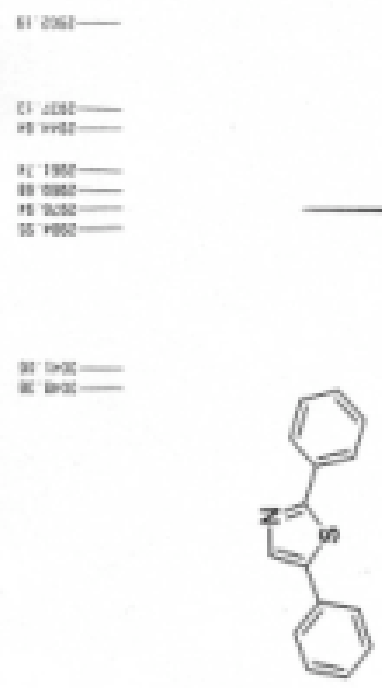

on-

on-

on-

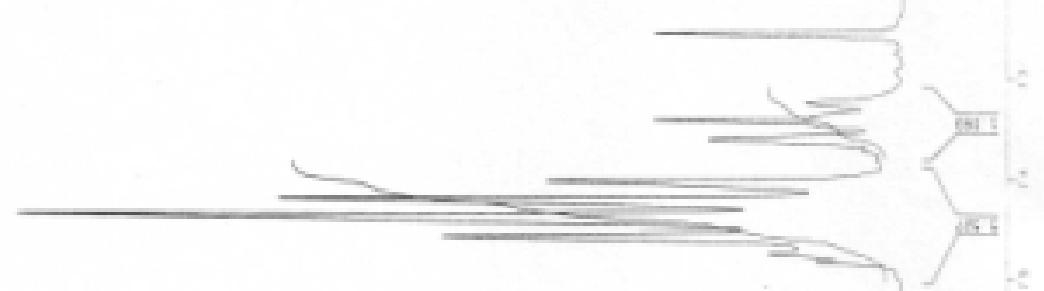

k

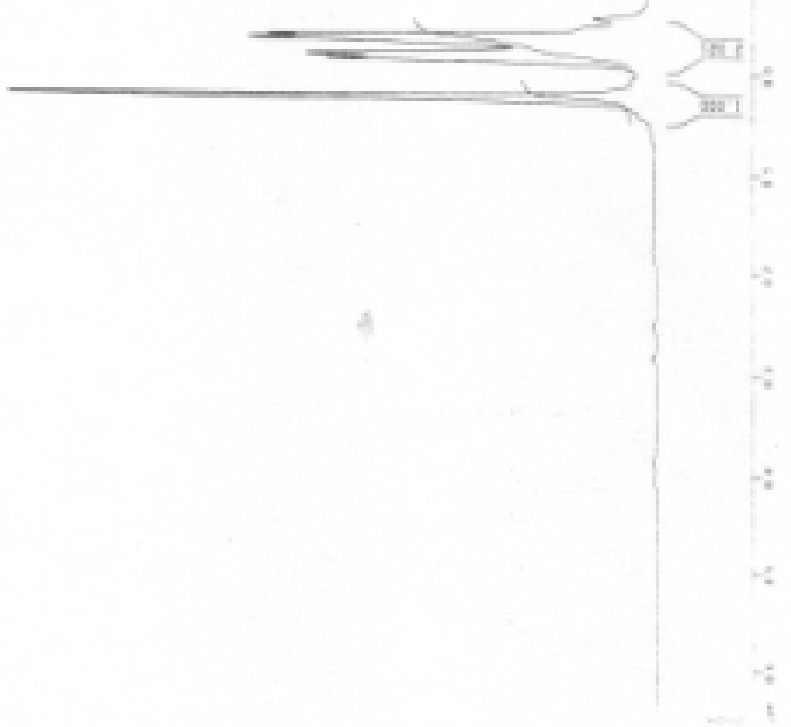

